\title{
The mass and energy balance of an integrated solution for municipal solid waste treatment
}

\author{
V. Torretta ${ }^{1}$, G. Ionescu ${ }^{2}$, M. Raboni ${ }^{1} \&$ G. Merler $^{2}$ \\ ${ }^{I}$ Department of Biotechnologies and Life Sciences, \\ University of Insubria, Italy \\ ${ }^{2}$ Department of Civil Environmental and Mechanical Engineering, \\ University of Trento, Italy
}

\begin{abstract}
This paper describes a study conducted to evaluate the best scenario regarding the integrated management of municipal solid waste (MSW) in a large basin in North of Italy. Three different scenarios were defined with various technological solutions, having as principal core the selective collection, the energy recovery and the modality of final disposal. The comparison was done considering both mass and energy balance, trying to focus on the most suitable solution. The solutions cannot be definitive without having also developed a survey on the environmental and economic sustainability of the various alternative cases. However, an assessment made by developing balances of mass and energy demonstrates that the more interesting and favorable scenarios involve greater energy recovery, in particular with gasification and anaerobic digestion of the organic matter.

Keywords: energy, mass balance, recovery, waste management.
\end{abstract}

\section{Introduction}

The main methods for waste disposal in the 27 countries of the European Union (EU-27) are landfilling (about 48\%) and recovery (about 47\%). The data vary greatly from country to country, from Bulgaria, where $99 \%$ of the waste is dumped, to the Netherlands, where $83 \%$ is recovered. Denmark (23\%), 
Belgium (15\%), Finland (13\%) and Sweden (10\%) are above the European average in terms of energy recovery [1].

The amount of recycled MSW increased from 21.8 million tons (46 kg per capita) in 1995 to 59.2 million tons (118 kg per capita) in 2009 [1]. Selective collection (SC) varies greatly from country to country but also from system to system $[2,3,4]$, with more significant increases for some types of waste, for example, waste electronic and electrical equipment (WEEE) and organic fraction municipal solid waste (OFMSW) $[5,6]$. The recovery of organic matter by composting is the treatment that increased the most, with an annual growth rate of $9.1 \%$. In general, the recovery of energy from organic fractions, not only by aerobic processes, but also through anaerobic digestion (AD), by exploiting the contribution of companies that operate in the fields of agriculture, zootechnology and the food industry, has had a significant boost [7-12]. There has been a constant increase in MSW incineration, from $65 \mathrm{~kg}$ per capita, in 1995 , to $101 \mathrm{~kg}$ per capita in 2009 , reaching recently $20 \%$ of the total amount of waste disposed [13], even if new plants are expected in areas with a high concentration of waste generation.

The choice of waste management system is linked to EU regulations and the laws of the marketplace. The integrated solutions applied to managing MSW must thus be based on the local situation, taking into account environmental problems, the renewable energy request at national and international level, the quantity and quality of the waste produced and the economic requirements $[4,14,15]$.

The environmental sustainability of the various solutions related to the choice processes typology and waste treatment plants is strategically important given the public's concern about environmental issues. Relaying information [16] is also very important in order to focus attention on waste treatment. Particularly with regard to environmental pressures and atmospheric pollution [17-23].

Based on the quality and quantity of waste produced in the province in Trento, northern Italy, a study was carried out to compare different scenarios related to different integrated waste management solutions.

\section{Materials and methods}

The chosen case-study, a province in the North part of Italy, occupies an area of $6207 \mathrm{~km}^{2}$. In 2010, the resident population was 524,826 . The annual production of waste is about 297,217 tons [24]. Three integrated MSW scenarios have been developed and are presented in this paper.

In the first scenario reported in Fig. 1:

- recyclable materials are sent to the market; the residues resulted from the residual waste (RMSW) processing and from the recycling line are exploited for energy (paper and cardboard, wood, plastic) through gasification after shredding; the residues that cannot be energetically recovered are landfilled;

- compostable materials: OFMSW is sent to $\mathrm{AD}$; produced biogas is collected and used in an internal combustion engine to produce electricity 
and heat. The digestate is sent to post-composting plant together with the green fraction. A part of the pre-treatment residues are subject to shredding and bio-drying treatment before being exploited for energy;

- materials recovery, treatment, disposal flows: the not reused fractions (textiles, WEEE, inert, bulky waste, waste swept from the road, etc.) are sent to dedicated disposal platforms.

In the case of RMSW, the bags are first opened mechanically, and the waste then undergoes magnetic separation system in order to recover valuable metals. The material that has had its metal part removed undergoes to a pressure-extrusion system, which separates the stream in two flows: wet and dry fractions. The residues of the pre-treatment and post-refining are added to the wet fraction, which is bio-dried in order to reduce the moisture present and to increase the LHV [25], before being sent to gasification. A ballistic separator is used to sort the combustible dry fraction. The syngas produced is first treated, and then flows into an internal combustion engine to produce electricity and heat; the slag from the gasification and syngas cleaning processes are landfilled (Fig. 1).

The second and third developed cases, have a slightly different scheme in comparison with the first one. In the second case the wet fraction coming out of the pressure extruder is sent for $\mathrm{AD}$ to produce biogas, and in the third is sent to thermal drying. In the third case, the thermal drying in addition to electricity, needs a considerable amount of heat, which will be recovered by exploiting the energy contained in the hot gases and in the cooling system of the cogenerator, which works thanks to the biogas that comes from the OFMSW anaerobic digestion.

In all the considered cases, the efficiency values and the parameters that relate to the various treatments, which are necessary to establish the balances, were determined from the technical literature, in particular: bag splitter (blade shredder: energy consumption), primary shredder (energy consumption), magnetic separation, extrusion, and ballistic separator (efficiency and energy consumption), internal combustion engine (running parameters), AD (running parameters and energy consumption), mechanical drying (running parameters and energy consumption), post-composting (energy consumption), thermal drying (thermal and energy consumptions), bio-drying (running parameters and energy consumption), gasification and syngas cleaning (running parameters and energy efficiency) [26-38]. Each process that transforms the waste into reusable material has its own recovery efficiency [26-38].

For the material sent for composting, $25 \%$ of residue of the total ingoing material was considered valid, as the sum of the residues for the pre-treatment of the material going into the $\mathrm{AD}$ and the residues from the refining of the compost, which take place at the end of the process.

The recycling of some fractions of the waste leads to some energy saving, preventing emissions into the atmosphere, and reduces the use of new raw materials for the production of consumer goods. To calculate the electrical and thermal energy saved, for inclusion in the overall costs, the distribution of the electrical/thermal consumption linked to the production of each type of recycled 
material was calculated. This distribution was then maintained to calculate the energy saved: steel 27,176 MJ/ton produced $_{\text {, aluminium 187,834 MJ/ton }}$ produced, glass $6424 \mathrm{MJ} / \mathrm{ton}_{\text {produced }}$, wood $29,438 \mathrm{MJ} / \mathrm{m}^{3}$ produced, paper $42,044 \mathrm{MJ} /$ ton $_{\text {produced }}$, plastic $72,573 \mathrm{MJ} /$ ton $_{\text {produced }}[39]$.

In order to take into account the possible degradation of the material produced from recycled matter, replacement rates were introduced for the paper, wood and plastic fractions: 1.0 for metals and glass, 0.6 for wood, 0.83 for paper and 0.85 for plastic 0.9 .

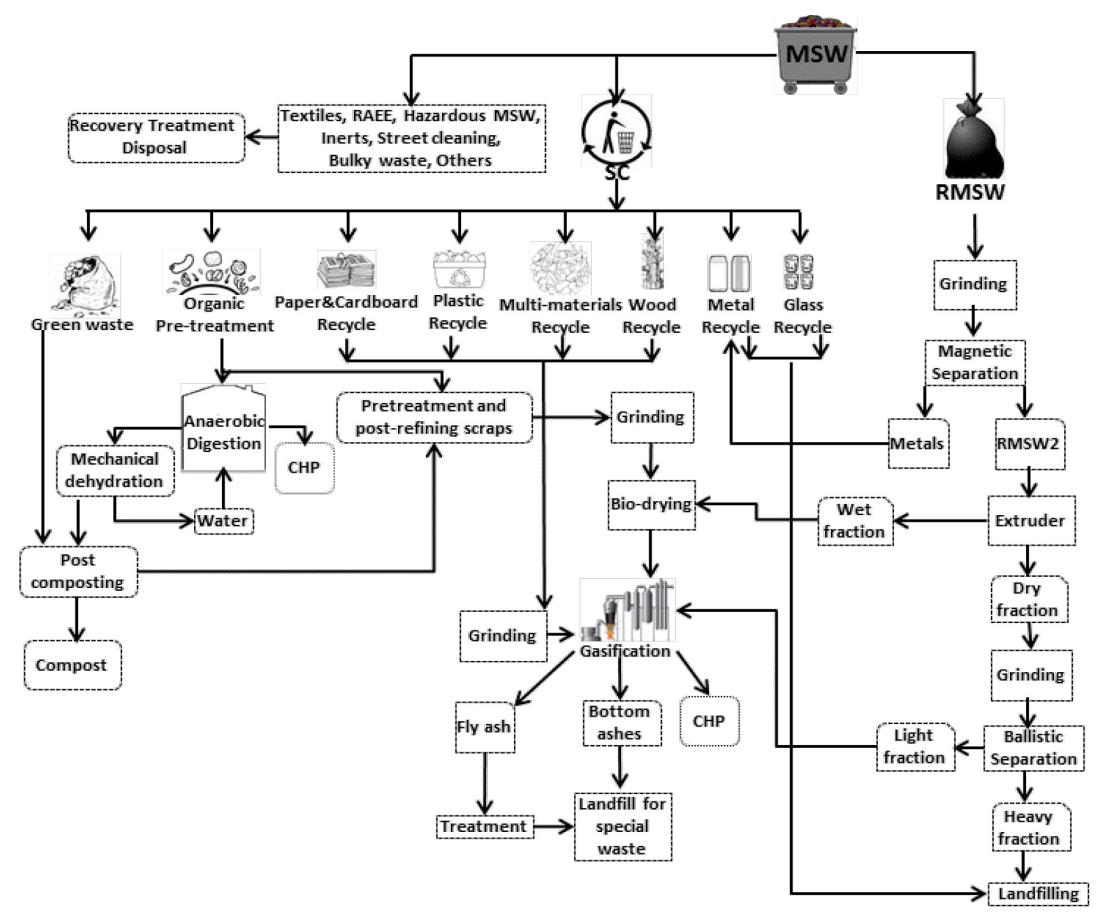

Figure 1: $\quad$ MSW treatments: scenario 1.

\section{Results and discussion}

Table 1 shows the final destinations in various scenarios, while Tables 2 and 3 show the mass and energy balances for scenario 1 .

Table 1: Final destination of the waste in the considered scenarios.

\begin{tabular}{|l|c|c|c|}
\hline & Case 1 & Case 2 & Case 3 \\
\hline Material to landfill & $12 \%$ & $11 \%$ & $12 \%$ \\
\hline Produced compost & $7 \%$ & $10 \%$ & $7 \%$ \\
\hline Recycled material & $28 \%$ & $28 \%$ & $28 \%$ \\
\hline Mass loss & $40 \%$ & $38 \%$ & $40 \%$ \\
\hline Material to be recovered, treated, disposed of & $13 \%$ & $13 \%$ & $13 \%$ \\
\hline
\end{tabular}


Table 2: Benchmarks in all cases.

\begin{tabular}{|l|c|c|c|c|c|c|}
\hline \multicolumn{1}{|c|}{ Flux } & \multicolumn{2}{|c|}{ Case 1 } & \multicolumn{2}{c|}{ Case 2 } & \multicolumn{2}{c|}{ Case 3 } \\
\hline Mass balance & $\begin{array}{c}\text { Mass } \\
{[\%]}\end{array}$ & $\begin{array}{c}\text { LHV } \\
{\left[\mathrm{kJ} \mathrm{kg}^{-1}\right]}\end{array}$ & $\begin{array}{c}\text { Mass } \\
{[\%]}\end{array}$ & $\begin{array}{c}\mathrm{LHV} \\
{\left[\mathrm{kJ} \mathrm{kg}^{-1}\right]}\end{array}$ & $\begin{array}{c}\text { Mass } \\
{[\%]}\end{array}$ & $\begin{array}{c}\mathrm{LHV} \\
{\left[\mathrm{kJ} \mathrm{kg}^{-1}\right]}\end{array}$ \\
\hline MSW & 100 & 9,883 & 100 & 9,883 & 100 & 9,883 \\
\hline RMSW & 33 & 14,439 & 33 & 14,439 & 33 & 14,439 \\
\hline Material from SC to recycling & 10 & 10,093 & 10 & 10,093 & 10 & 10,093 \\
\hline $\begin{array}{l}\text { Material from SC to biological } \\
\text { treatment }\end{array}$ & 13 & 4,160 & 13 & 4,160 & 13 & 4,160 \\
\hline Material from SC to other treatment & 13 & 6,803 & 13 & 6,803 & 13 & 6,803 \\
\hline Metals from RMSW to recycling & 1 & 0 & 1 & 0 & 1 & 0 \\
\hline Residuals from SC to landfill & 1 & 0 & 1 & 0 & 1 & 0 \\
\hline $\begin{array}{l}\text { Residuals from pre-treatment and post } \\
\text { refinement }\end{array}$ & 5 & 22,706 & 5 & 22,706 & 5 & 22,706 \\
\hline Residuals from recycling and treatment & 6 & 12,685 & 6 & 12,685 & 6 & 12,685 \\
\hline Material to press-extrusion & 32 & 14,899 & 32 & 14,899 & 32 & 14,899 \\
\hline Dry fraction to ballistic separation & 23 & 17,766 & 23 & 17,766 & 23 & 17,766 \\
\hline Wet fraction to drying process & 9 & 8,020 & & & 9 & 8,020 \\
\hline Bio-dried fraction & 11 & 17,144 & & & 6 & 9,514 \\
\hline Wet fraction to anaerobic digestion & 9 & 8,020 & 9 & 8,020 & 9 & 8,020 \\
\hline $\begin{array}{l}\text { Digested dehydrated from RMSW to } \\
\text { post-composting }\end{array}$ & 11 & 17,144 & 7 & - & 11 & 17,144 \\
\hline Light fraction & 19 & 20,239 & 19 & 20,239 & 19 & 20,239 \\
\hline Heavy fraction to landfill & 3 & 3,024 & 3 & 3,024 & 3 & 3,024 \\
\hline Material to landfill & 4 & 2,335 & 3 & 3,024 & 4 & 2,335 \\
\hline Material to gasification & 36 & 18,111 & 36 & 19,283 & 6 & 17,649 \\
\hline Bottom ash & 6 & - & & & 1 & - \\
\hline Residuals from syngas treatment & 1 & - & & & 1 & - \\
\hline Material to landfill for hazardous waste & 8 & - & 7 & - & 8 & - \\
\hline Produced compost & 7 & - & 30 & - & 7 & - \\
\hline
\end{tabular}

It is interesting to note the mass loss due to the different treatments provided in the system and determined essentially by the loss of moisture or volatile solids. The AD exploits the content of carbon, hydrogen and oxygen present in the waste for the production of biogas, while the bio-drying increases the temperature in the waste, and decreases the moisture involving the use of a part of volatile solids. Compost production consumes the volatile solids in the degradation of the organic substance, while thermal drying causes a loss of water, and finally the thermal treatment breaks down what remains of the moisture and volatile solids.

Considering the global energy balance (Table 3) in the first scenario the amount produced by the whole system is greater than the consumed one. Only $21 \%$ of the electricity produced, and $3 \%$ of that thermal energy produced is required for the operation of the system. The other two scenarios have similar behavior. Table 4 shows the values of energy saved by recycling materials that replace each percentage in the material produced from virgin raw materials.

The total electrical energy transferred to the electric network is equal to $120 \mathrm{GWh}$ per year, while the thermal energy is $165 \mathrm{GWh}$. 
Table 3: Total energy.

\begin{tabular}{|c|c|c|c|c|c|c|}
\hline & \multicolumn{2}{|c|}{ Case 1} & \multicolumn{2}{|c|}{ Case 2} & \multicolumn{2}{|c|}{ Case 3} \\
\hline PRODUCED & {$\left[\mathrm{kWh} \mathrm{t}^{-1}\right]$} & {$\left[\mathrm{GWh} \mathrm{y}^{-1}\right]$} & {$\left[\mathrm{kWh} \mathrm{t}^{-1}\right]$} & {$\left[\mathrm{GWh} \mathrm{y}^{-1}\right]$} & {$\left[\mathrm{kWh} \mathrm{t}^{-1}\right]$} & {$\left[\mathrm{GWh} \mathrm{y}^{-1}\right]$} \\
\hline Gasifier, electric energy & 1,359 & 144,399 & 1,447 & 130,47 & 1,324 & 141,146 \\
\hline AD, electric energy & 209 & 7,612 & 209 & 7,612 & 209 & 7,612 \\
\hline $\begin{array}{l}\text { From RMSW, electric } \\
\text { energy }\end{array}$ & - & - & 343 & 9,55 & - & - \\
\hline Gasifier, thermal energy & 1,532 & 162,797 & 1,631 & 147,098 & 1,493 & 159,130 \\
\hline $\mathrm{AD}$, thermal energy & 214 & 7,780 & 214 & 7,780 & 214 & 7,780 \\
\hline $\begin{array}{l}\text { From RMSW, thermal } \\
\text { energy }\end{array}$ & - & - & 350 & 9,762 & - & - \\
\hline CONSUMED & - & - & - & - & - & - \\
\hline First open bags grinding & 3 & 293 & 3 & 293 & 3 & 293 \\
\hline Deferrization & 1 & 127 & 1 & 127 & 1 & 127 \\
\hline Press-extruder & 11 & 1,043 & 11 & 1,043 & 11 & 1,043 \\
\hline Primary grinding & 12 & 1,185 & 12 & 1,197 & 12 & 1,185 \\
\hline Ballistic separator & 1 & 50 & 1 & 50 & 1 & 50 \\
\hline Bio-dryer & 33 & 1,420 & & & 33 & 1,420 \\
\hline Electric dryer & - & - & - & - & 93 & 1,358 \\
\hline Thermal dryer & - & - & - & - & 930 & 13,580 \\
\hline $\begin{array}{l}\text { Gasifier and gas } \\
\text { treatment }\end{array}$ & 202 & 23,104 & 215 & 20,87 & 196 & 22,583 \\
\hline $\begin{array}{l}\text { AD pre-treatments } \\
\text { (grinding and sieving) }\end{array}$ & 13 & 583 & 13 & 583 & 13 & 583 \\
\hline $\mathrm{AD}$, electric & 30 & 1,091 & 30 & 1,09 & 30 & 1,091 \\
\hline $\mathrm{AD}$, thermal & 107 & 3,902 & 107 & 3,902 & 107 & 3,902 \\
\hline Sludge dewatering & 6 & 758 & 6 & 758 & 6 & 758 \\
\hline $\begin{array}{l}\text { Sludge dewatering from } \\
\text { RMSW }\end{array}$ & - & - & 6 & 889 & & \\
\hline $\begin{array}{l}\text { Pre-treatment before } \\
\text { composting }\end{array}$ & 12 & 188 & 12 & 188 & 12 & 188 \\
\hline Composting & 20 & 942 & 20 & 1,362 & 20 & 942 \\
\hline $\begin{array}{l}\text { Post refinement } \\
\text { (sieving) }\end{array}$ & 1 & 27 & 1 & 37 & 1 & 27 \\
\hline $\begin{array}{l}\text { Electric energy } \\
\text { consumption for } \\
\text { management }\end{array}$ & - & 1,200 & - & 1,200 & - & 1,200 \\
\hline $\begin{array}{l}\text { Thermal energy } \\
\text { consumption for } \\
\text { management }\end{array}$ & - & 1,000 & - & 1,000 & - & 1,000 \\
\hline TOTAL electric & - & 32,010 & - & 30,531 & - & 31,428 \\
\hline TOTAL thermal & - & 4,902 & - & 9,596 & - & 18,481 \\
\hline $\begin{array}{l}\text { PARTIAL BALANCE } \\
\text { (E.E.): }\end{array}$ & - & 120,001 & - & 117,106 & - & 117,331 \\
\hline $\begin{array}{l}\text { PARZIAL BALANCE } \\
\text { (Thermal Energy) }\end{array}$ & - & 165,676 & - & 155,044 & - & 148,429 \\
\hline \multicolumn{7}{|c|}{ Energy saved thanks to recycling } \\
\hline Electric energy & - & 139,008 & - & 139,008 & - & 139,008 \\
\hline Thermal energy & - & 139,131 & - & 139,131 & - & 139,131 \\
\hline $\begin{array}{l}\text { GLOBAL BALANCE } \\
\text { (E.E.): }\end{array}$ & - & 259,009 & - & 256,114 & - & 256,338 \\
\hline $\begin{array}{l}\text { GLOBAL BALANCE } \\
\text { (Thermal Energy) }\end{array}$ & - & 304,807 & - & 294,175 & - & 287,560 \\
\hline
\end{tabular}


Table 4: $\quad$ Energy saved by recycling materials instead of producing from raw materials.

\begin{tabular}{|c|c|c|}
\hline \multicolumn{3}{|c|}{ Case 1-2 - - } \\
\hline Type of material & Electrical energy $[\mathrm{GWh}]$ & Thermal energy $\left[\mathrm{GWh}_{\text {th }}\right]$ \\
\hline Metal & 8,339 & 7,553 \\
\hline Wood & 121 & 9,946 \\
\hline Glass & 7,895 & 39,942 \\
\hline Paper & 113,435 & 67,521 \\
\hline Plastic & 9,217 & 14,169 \\
\hline
\end{tabular}

Calculation showed that an average of $59 \mathrm{kWh} \mathrm{t}^{-1}$ and $64 \mathrm{kWh}_{\mathrm{th}} \mathrm{t}^{-1}$ of electrical and thermal energy in all scenarios are needed to treat organic and green waste from selective collections. The obtained energy $\left(209 \mathrm{kWh} \mathrm{t}^{-1}\right.$ and $214 \mathrm{kWh}_{\text {th }} \mathrm{t}^{-1}$ electrical and thermal) is abundantly greater than that consumed, and thus the balance is positive.

In the first case, the balance is positive because the energy production is far higher than the energy consumption for the waste treatment. The specific electrical energy cost to treat RMSW and residues from recycling and composting as input to the gasifier is $278 \mathrm{kWh} \mathrm{t}^{-1}$. The consumptions necessary for these treatments, including the self-consumption of the gasifier, are equal to $19 \%$ of the electricity produced.

The gasifier is quite energy-intensive as is the process of bio-drying of the wet fraction from the press-extruder, while the other treatments are relatively inexpensive in terms of energy consumption. The high energy production from the gasifier is due to the high energy content of the feed material; its net electrical efficiency reaching a value of $23 \%$. The LHV of gasifier input increased by $24 \%$ starting from the moment in which the waste enters the process at the point when it is fed to the gasification. Of course this balanced by a decrease of the mass flow.

In the second case, the energy produced is again far greater than the energy consumed. The total energy transferred to the electric network is $117 \mathrm{GWh}$ annually, while the thermal energy is $155 \mathrm{GWh}_{\text {th. }}$. In this scenario there is an additional source of electricity production represented by the second anaerobic digestion plant. The pre-treatments for the gasification required an electricity consumption of $254 \mathrm{kWh} \mathrm{t}^{-1}$. The consumption requested for the treatments, including the gasifier self-consumption are $18 \%$ and $3 \%$ respectively of the electricity and thermal energy produced. By bringing a mix of materials to the gasifier with a high energy content (more than $19,000 \mathrm{~kJ} \mathrm{~kg}^{-1}$ ), low moisture $(20 \%)$ and low content of NVS (13\%), good results can be obtained in terms of the amount of energy produced from the syngas.

In the third case, the overall energy balance is positive, but less than the previous cases because the waste thermal drying consumes a significant amount of energy. The energy consumed to ensure the operation of the integrated waste management, is $21 \%$ of the electricity and $11 \%$ of the thermal energy produced. The total annual energy transferred to the network is $117 \mathrm{GWh}$, while the 
thermal energy is $148 \mathrm{GWh}_{\text {th. }}$. The treatments needed before gasification required an electricity consumption of $272 \mathrm{kWh} \mathrm{t}^{-1}$ of electricity and $139 \mathrm{kWh}_{\mathrm{th}} \mathrm{t}^{-1}$ of thermal energy.

The first case is the best from the point of view of electricity production followed closely ( $4 \div 5 \mathrm{GWh}$ less) by the second one. The exploitation of energy from biological treatment does not significantly influence the balance.

\section{Conclusions}

The present study has highlighted how difficult it is to determine a priori the best technologies for the waste management, regardless of the composition of the waste, the plant size and location in the territory. An environmental analysis certainly could help to define which technologies together have a minor impact. The energy balance helps to determine the most efficient way to recover the energy contained in the waste. The mass balance is necessary for the correct dimensioning of the various plants. Thus, all these analyses (together with the financial evaluation) are necessary to determine a correct MSW integrated system. However the proposed systems must take into account the social and geographical context, and may also help to foster any changes in the lifestyle and routines of the local population which are needed for the entire waste cycle to be managed correctly.

Of course, the study assumes that the technical solutions contained in the various scenarios are environmentally and economically sustainable and that the market is able to receive flows from recycling, and the production of compost, etc.

Referring to the considered scenarios, the first two cases appear to be preferable in the context of the considered area. Nonetheless, the first scenario has its merit in obtaining a higher production of electricity and heat, while the second scenario ensures a greater production of compost (assuming that this does not constitute a problem for the identification of the end users). The last scenario is less interesting. The presence of an anaerobic digester does not affect the global energy balance much. Exploiting a thermal dryer is not sustainable due to the high energy consumption.

As a future step the authors planned to develop a sensitivity analysis in order to better understand the differences among the presented scenarios.

\section{References}

[1] European Union. Eurostat pocketbooks: Energy, transport and environment indicators. ISSN 1725-4566, Bruxelles, Belgium, 2010.

[2] Rada, E.C., Ragazzi, M. \& Fedrizzi, P. Web-GIS oriented systems viability for municipal solid waste selective collection optimization in developed and transient economies, Waste Management 33(4), pp. 785-792, 2013. 
[3] Punkkinen, H., Merta, E., Teerioja, N., Moliis, K. \& Kuvaja E. Environmental sustainability comparison of a hypothetical pneumatic waste collection system and a door-to-door system, Waste Management 32(10), 1775-1781, 2012.

[4] Rada, E.C. Effects of MSW selective collection on waste-to-energy strategies. WIT Transactions on Ecology and the Environment, 176, 215-223, 2013.

[5] Torretta, V., Istrate, I., Rada, E.C. \& Ragazzi, M. Management of waste electrical and electronic equipment in two EU countries: a comparison, Waste Management, 33(1), pp. 117-122, 2013.

[6] Lorenz, H., Fischer, P., Schumacher, B. \& Adler, P. Current EU-27 technical potential of organic waste streams for biogas and energy production, Waste management, 33(11), pp. 2434-2448, 2013.

[7] Vaccari, M., Torretta, V. \& Collivignarelli, C. Effect of Improving Environmental Sustainability in Developing Countries by Upgrading Solid Waste Management Techniques: A Case Study, Sustainability, 4, pp. 2852-2861, 2012.

[8] Morris, J., Matthews, H.S. \& Morawski, C. Review and meta-analysis of 82 studies on end-of-life management methods for source separated organics, Waste Management, 33(3), pp. 545-551, 2013.

[9] Martinez, S.L., Torretta, V., Vázquez Minguela, J., Siñeriz, F., Raboni, M., Copelli, S., Rada, E.C. \& Ragazzi, M. Treatment of effluents from slaughterhouses using anaerobic filters, Environmental Technology. Article in press, doi: 10.1080/09593330.2013.827729.

[10] Callegari, A., Torretta, V. \& Capodaglio, A.G. Preliminary trial application of biological desulfonation in anaerobic digestors from pig farms, Environmental Engineering and Management Journal, 12(4), pp. 815-819, 2013.

[11] Rada, E.C., Ragazzi, M. \& Torretta, V. Laboratory-scale anaerobic sequencing batch reactor for treatment of stillage from fruit distillation, Water Science \& Technology, 67(5), pp. 1068-1074, 2013.

[12] Torretta, V., Rada, E.C., Istrate, I.A. \& Ragazzi, M. Poultry manure gasification and its energy yield, UPB-Scientific Bulletin, Series D, 75(1), pp. 231-238, 2013.

[13] Blumenthal, K. Generation and treatment of municipal waste, Eurostat Statistic, Bruxelles, Belgium. 2011.

[14] Ionescu, R.D., Ragazzi， M., Battisti， L., Rada， E.C. \& Ionescu， G. Potential of electricity generation from renewable energy sources in standard domestic houses, WIT Transactions on Ecology and the Environment, 176, pp. 245-253, 2013.

[15] Caramiello, C., Fabbri, L., Marzi, M. \& Tatàno, F. Tourism impact on municipal solid waste: Elaborations for the case study "Adriatic Riviera" (Province of Rimini, Italy), WIT Transactions on Ecology and the Environment, 122, pp. 471-482, 2009. 
[16] Di Mauro, C., Bouchon, S. \& Torretta, V. Industrial risk in the Lombardy Region (Italy): what people perceive and what are the gaps to improve the risk communication and the participatory process, Chemical Engineering Transactions, 26, pp. 297-302, 2012.

[17] Ionescu, G., Zardi, D., Tirler, W., Rada, E.C. \& Ragazzi, M. A critical analysis of emissions and atmospheric dispersion of pollutants from plants for the treatment of residual municipal solid waste, UPB Scientific Bulletin, Series D, 74(4), pp. 227-240, 2012.

[18] Torretta, V., Rada, E.C., Panaitescu, V.N. \& Apostol, T. Some consideration on particulate generated by traffic, UPB-Scientific Bulletin, Series D, 74(4), pp. 241-248, 2012.

[19] Ragazzi, M. \& Rada, E.C. Multi-step approach for comparing the local air pollution contributions of conventional and innovative MSW thermochemical treatments, Chemosphere, 89(6), pp. 694-701, 2012.

[20] Torretta, V., Raboni, M., Copelli, S., Rada, E.C., Ragazzi, M., Ionescu, G., Apostol, T. \& Badea, A. Application of strategies for particulate matter reduction in urban areas: an Italian case, UPB-Scientific Bulletin, Series D, 75(4), pp. 221-228, 2013.

[21] Ma, D., Deng, J. \& Zhang, Z. Comparison and improvements of optimization methods for gas emission source identification, Atmospheric Environment, 81, pp. 188-198, 2013.

[22] Ragazzi, M., Tirler, W., Angelucci, G., Zardi, D. \& Rada, E.C. Management of atmospheric pollutants from waste incineration processes: The case of Bozen, Waste Management and Research, 31(3), pp. 235-240, 2013.

[23] Ragazzi, M., Torretta, V., Ionescu, G. \& Istrate, I.A. Maintenance strategies and local impact of MSW incinerators, WIT Transactions on Ecology and the Environment,176, pp. 235-244, 2013.

[24] ADEP, Agenzia per la depurazione ufficio rifiuti. www.adep.provincia.tn.it/.

[25] Rada, E.C., Ragazzi, M., Badea, A. MSW Bio-drying: Design criteria from A 10 years research, UPB Scientific Bulletin, Series D, 74(3), pp. 209-216, 2012.

[26] Consonni, S., Giugliano, M. \& Grosso, M. Alternative strategies for energy recovery from municipal solid waste. Part A: mass and energy balances, Waste Management, 25, pp. 123-135, 2005.

[27] Ionescu G., Rada E.C., Ragazzi M., Marculescu C., Badea A. \& Apostol T. Integrated municipal solid waste scenario model using advanced pre-treatment and waste to energy processes, Energy Conversion and Management, 76 pp. 1083-1092, 2013.

[28] Cogeneration. Jenbacher gas engines Technical Specification JMS 320 GS-B.L 1.063kW el. http://www.cogeneration.com.ua/img/zstored/ J320V21_en.pdf

[29] Rada, E.C., Franzinelli, A., Taiss, M., Ragazzi, M., Panaitescu, V. \& Apostol, T. Lower Heating Value Dynamics during Municipal Solid Waste Bio-Drying, Environmental Technology, 28(4), pp. 463-470, 2007. 
[30] Fabbri, C. \& Piccinini, S. Biogas for Europe's future. Proc. of La filiera biogas il digestato, Ferrara, Italy, May 2011.

[31] Blengini, G.A. \& Fantoni, M. Life cycle assessment of alternative scenarios for OFMSW management. Proceedings of XI National Conference on Composting. Ecomondo, Rimini, Italy, 28 October 2009.

[32] Ghezzi, U. Thermal treatment of sludges. Technical report. Polytechnic of Milan, Italy. 2008.

[33] Ionescu, G \& Rada, E.C. Material and energy recovery in a Municipal Solid Waste System: Practical Applicability, International Journal of Environment and Resource, 1(1), 26-30, 2012.

[34] Lombardi, F., Lategano, E., Cordiner, S. \& Torretta, V. Waste incineration in rotary kilns: a new simulation combustion's tool to support design and technical change. Waste Management and Research. 31(7), pp. 739-750, 2013.

[35] Hera Group. Waste to energy treatment. Proceedings of SAIE 2008, Bologna, Italy, 18 October 2008.

[36] Arena, U. Process and technological aspects of municipal solid waste gasification. A review, Waste Management, 32, pp. 625-639, 2012.

[37] Rigamonti, L., Grosso, M. \& Giugliano, M. Life cycle assessment of sub-unit composing a MSW management system, Journal of Cleaner Production, 18, pp. 1652-1662, 2010.

[38] Blengini, G.A., Genon, G. \& Fantoni, M. LCA del sistema integrato dei RSU nella Provincia di Torino. Politecnico di Torino, DITAG, DISPEA, Turin, Italy. 2008.

[39] Rigamonti, L, Grosso, M \& Giugliano, M. Life cycle assessment for optimising the level of separated collection in integrated MSW management systems. Waste Management, 29, pp. 934-44, 2009. 